\title{
Analysis of the Key Challenges Facing Potato Farmers in Oljoro-Orok Division, Kenya
}

\author{
Amon Mwangi Karanja, Chris Shisanya, George Makokha \\ Kenyatta University, Nairobi, Kenya \\ Email: amonmwangi@yahoo.com \\ Received 17 June 2014; revised 19 July 2014; accepted 2 August 2014 \\ Copyright (C) 2014 by authors and Scientific Research Publishing Inc. \\ This work is licensed under the Creative Commons Attribution International License (CC BY). \\ http://creativecommons.org/licenses/by/4.0/

(c) (i) Open Access

\begin{abstract}
The objective of this study was to evaluate the key challenges facing potato production in OljoroOrok division. Primary data were obtained from randomly selected farmers through questionnaires. Purposive sampling was used to select 300 farmers in the division. Proportionate sampling was used to select the sample of farmers in each of the four locations. The data collected were analyzed using descriptive statistics namely frequencies, percentages and means with the aid of Statistical Package for Social Science (SPSS) version 17.0 and a SWOT matrix computed. Rainfall variations, lack of clean seeds and crop diseases have been found to be the major challenges facing potato production in the division. $45 \%$ of the respondents see rainfall variation as the main cause of decreased potato yields, $33 \%$ lack of clean seeds and $6 \%$ crop diseases. The study found that farmers use crop diversification and off season approaches to adapt to rainfall variability. The study recommends adaptation measure to be applied to cope with rainfall variation. Such measures include irrigation using water available in Jacob, Terracin and Kivindo dams during dry spelt. A lot of emphases on the use of certified seeds should be done by the agriculture field officers to caution farmers from planting the same potatoes they harvested in the previous harvest.
\end{abstract}

\section{Keywords}

Key Challenges, Rainfall Variations, Crop Diseases and Potato Yields

\section{Introduction}

According to Obare et al. [2010] [1] Irish potato production in Oljoro-Orok is characterised by decreasing returns to scale with a mean allocative efficiency of 0.57 . Substantial productivity gains can be obtained by improving the allocative efficiency of Irish potato producers. To achieve this, the government and stakeholders in the Irish potato sector should attempt to create a favourable institution environment that would facilitate the 
farmers' access to formal credit.

According to Ministry of Agriculture (1998) [2] increase in potato production occurs simultaneously with increased production of cereals and other staple crops, principally maize, largely attributable to average rainfall in areas of cereal production. The increase in maize in 1998 was especially notable given action taken by the Kenyan Government to encourage maize production, via tariffs on imported maize that might otherwise be more cheaply available to consumers thus encouraging farmers to put more land under maize (Nyoro 2002) [3]. According to Moock (1973) [4] the withdrawal of household labour through male to labour migration, off-farm employment and school participation of children have led to major changes in the structure of the division of labour. One of the consequences of these processes is the expansion of women's roles in reproduction and production. The study showed that women in western Kenya make a significant contribution to agricultural production. They are very heavily involved in crop production and household activities. Their involvement in livestock production is culturally defined and structurally circumscribed even though when the children and male heads of household are away, women combine livestock activities with their traditional responsibilities.

According to McCalla (1994) [5] new lands that can be put under agriculture are limited, contrary to the last three decades, where the bulk of food production in Sub-Saharan Africa came from expansion of agricultural lands. The opportunities to increase crop yields under rain-fed agriculture strongly rest on focusing our attention on maximizing yield per unit of water applied. In order to formulate and adopt appropriate and adequate options for increasing productivity in rain-fed agriculture, it is worthwhile to have an understanding into the performance of this sector from trends analysis of the productivity of potato cultivated under rainfall. Such insight enabled the study to evaluate possible factors that dictate productivity of potato in rain-fed agriculture division like Oljoro-Orok.

According to Kuyiah (2007) [6] cash constraints and small land sizes are the two most important factors that inhibit realization of higher farm incomes and optimal production at farm level. There is a need for policies that spur investment in public infrastructure, rural financial markets, private investment, and support institutions to address the problems of high transaction costs to investors, and reduce risks faced by farmers. The drought cycle in Kenya dates back to more than three decades ago. In 1975, widespread drought affected 16,000 people; in 1977 ther was 20,000 people affected; in 1980, 40,000 people suffered the effects of drought; and in 1983/84 it hit over 200,000 people. In 1991/92 in Arid and Semi-Arid Districts of North Eastern Kenya, the Rift Valley, Eastern and Coastal Provinces, 1.5 million people were affected by drought. It was reported that widespread drought affected 1.4 million people in 1995/96 and in 1999/2000, famine affected close to 4.4 million people. In 2004, 3 million people were in dire need of relief aid for eight months from August 2004 to March 2005 due to widespread drought. The drought in 2008 affected 1.4 million people. In the late 2009 and early 2010, 10 million people were at risk of hunger after harvests failed due to drought (Mateche, 2011) [7]. Oljoro-Orok division being one of the main Irish potatoes producing division in Nyandarua County necessitated the study of the key challenges affecting potato farming in Oljoro-Orok division.

\section{Material and Methodology}

The study area was Oljoro-Orok division, Nyandarua County situated in the central part of Kenya. The division lies between Latitude $0^{\circ} 8^{\prime}$ north and $0^{\circ} 40^{\prime}$ South and between $35^{\circ} 13^{\prime}$ East and $36^{\circ} 22^{\prime}$ East between the Rift Valley and Aberdare Ranges. Farming is the main economic activity within the division. The lower zone of the division namely Lesirko and lower side of Oraimutia locations have the laterites soils. Land size per household varies across the divisions but with an average of 2 hectares. The growing seasons are largely determined by rainfall patterns. In Oljoro-Orok there are two distinct rain seasons occurring between February-June and October-December (Kaguongo, et al., 2007) [8]. Potatoes are the major cash crop in the division. Farmers in OljoroOrok sell their produce to middlemen who transport the potatoes to major markets in Nairobi, Nakuru and Mombasa. The most commonly accepted unit of marketing potatoes is the sisal bag of roughly $100 \mathrm{kgs}$. However major urban centres like Nairobi demand an "extended bag" (with sisal net extension woven onto each bag which weigh from 110 - $150 \mathrm{~kg}$ (MoA, 2007) [9] as shown on Figure 1. The extended bag has been used to deny growers their rightful share of the revenue as the bag is sold at similar prices to the ordinary bag and no reference to weight is made.

The study employed purposeful sampling design; this approach seeks to collect data from $10 \%$ of the total population. The main factors to consider in determining the sample size is the need to have it manageable 


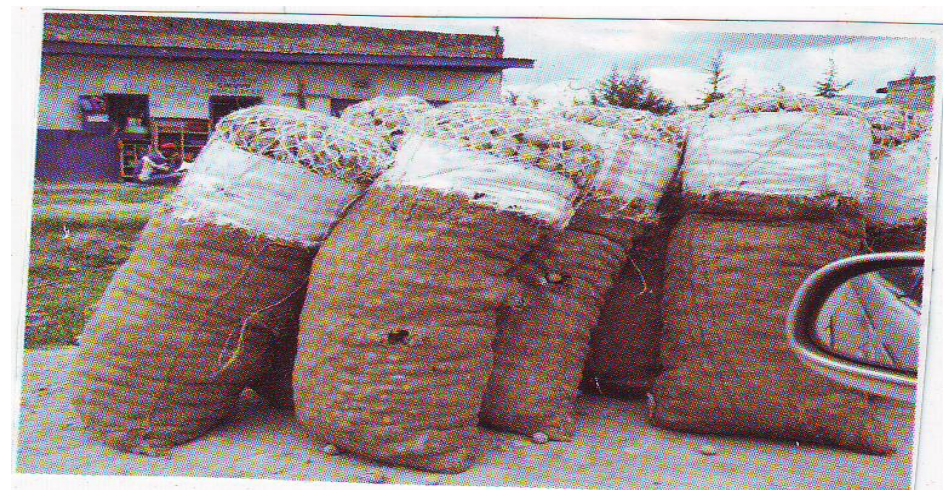

Figure 1. Potato bags with sisal net extension woven onto each bag which weighs from $110-150 \mathrm{~kg}$.

enough and derive detailed data at an affordable cost in terms of time, finances and human resource (Neumann, 2000) [10]. The population was 3000 household in Oljoro-Orok division (KNBS, 2009) [11] and in this regards $10 \%$ translated to 300 households. Areas were clustered into location forming the basis of selecting the sample population in each Location. The sample in each location was computed based on the population proportion using the following formula;

$$
n=p / \mu \times 300
$$

where

$n$ is the sample population of the division;

$n=82$ Oraimutia Location;

$n=48$ Nyairoko Location;

$n=170$ Lesirko Location;

$p$ is the population of the household in the location;

$\mu$ is the total households in the division.

The data were analysed using statistical software namely SPSS version 17 and SAS for windows version 8. Frequencies, percentages and proportions were used in interpreting the respondents' perception of issues raised in the questionnaire.

\section{Results and Discussion}

The study found rainfall variation, and lack of clean seeds as the main threats to potato farming. As shown in Figure 2, majority of the respondents $45 \%$ agrees that rainfall variation is the main cause of decreased Irish potato yields in Oljoro-Orok division. 33\% lack of clean seeds, $8 \%$ soil degeneration, $6 \%$ diseases and high cost of farm inputs while $2 \%$ see inadequate field officers as the cause of decreased potato yields. Rainfall is the only source of water to the Irish potatoes in the division and therefore means that a variation of rainfall leads to variations of potato yields.

Lack of clean seeds which has been found to be the second major threat to potato farming cause low yields since farmers do not get certified varieties which can do best in their areas and which can be stored for a long time after harvesting to cushion them against poor selling prices. Other challenges that have been identified include; inadequate field officers which denies farmers vital information on the best seeds to be planted on which soils, in which quantities and where. Potato diseases such as potato blight have also led to pre-harvest and post harvest losses in the division. The findings support the earlier work by Olanya et al. (2004) [12] that late blight and bacterial wilt were regarded by farmers in Nyandarua as the most common diseases. Field officers are supposed to inform farmers on the scientific methods of farming, the best pesticides to use, the best types of seeds to plant and the right spacing to plant the potato seeds in the division. When the officers are few, farmers lack the much needed advice on the scientific methods of farming which leads to low yields.

\section{Conclusion and Recommendations}

Potato farmers in Oljoro-Orok division face several challenges. Rainfall variation, lack of clean seeds, soil dege- 


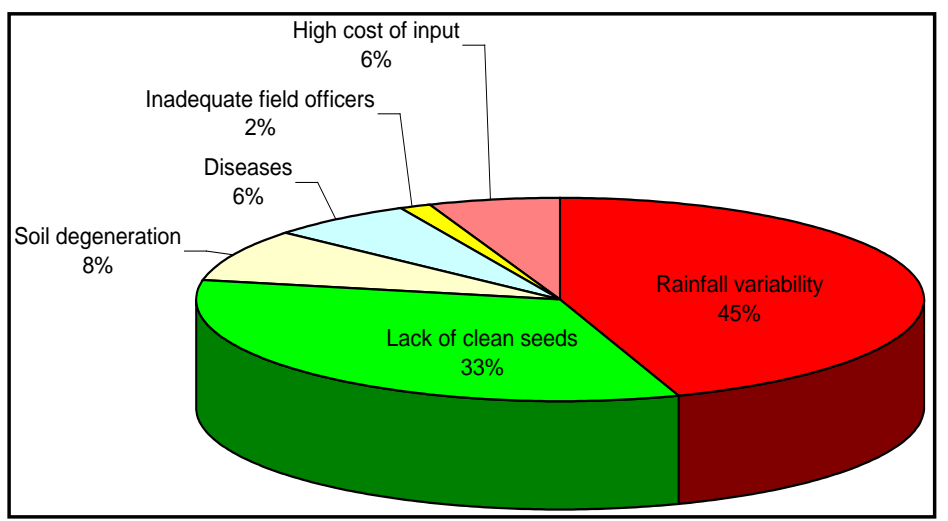

Figure 2. Key challenges facing Irish potato farmers.

neration, diseases, high cost of farm inputs and inadequate field officers are found to be the major challenges that potato production is facing. Clean seeds are either not available or when available they are very expensive and farmers can't afford to buy them. Agricultural field officers are few as compared to farmers and this has denied the farmers an opportunity to receive vital scientific knowledge necessary to increase their production. The study reveals that most farmers in Oljoro-Orok division plant according to traditions, not according to seasonal weather forecast from Kenya Meteorological Department. Planting according to tradition leaves farmers vulnerable in case of unforeseen change of onset. From the findings, the named challenges: rainfall variations, lack of clean seeds, inadequate field officers and pest and diseases can be solved if the crop still remains economical to plant in Oljoro-Orok division. Irish potato matures within a short period of time and this enables the farmers to plant two seasons in a year unlike maize which take one year to mature in Oljoro-Orok Division.

\section{Recommendations}

The study came up with the following recommendations:

Clean seeds should be made available at affordable cost so that more farmers can plant them to reduce losses resulting from diseases and other negative traits such as low resistance to drought that are passed by planting the same harvested seeds.

Farmers should be advised on importance of timely planting to enable plants to utilise the available rains at their different stages of growth i.e. flowering and maturity.

More extension officers should be employed so that they can be enough to attend all farmers. This will enable them to reach farmers at the shortest time possible especially to emphasis on the importance of seasonal weather forecast whenever they are relied.

More research should be done on potato variety that can grow with little amount of water and matures within a short period of time so that when timely planted it can mature before the dry spelt.

\section{References}

[1] Obare, G., Nyagaka, D., Nguyo, W. and Mwakubo, S. (2010) Are Kenyan Smallholders Allocatively Efficient? Evidence from Irish Potato Producers in Nyandarua North District, Egerton University Found, Egerton.

[2] Ministry of Agriculture (1998) Annual Report for 1998.

[3] Nyoro, J. (2002) Kenya’s Competitiveness in Domestic Maize Production: Implications for Food Security. Tegemeo Institute, Egerton University, Kenya.

[4] Moock, P. (1973) Managerial Ability in Small-Farm Production: An Analysis of Maize Yields in the Vihiga Division of Kenya. Ph.D. Thesis, Columbia University, New York.

[5] McCalla, A.F. (1994) Agriculture and Food Needs to 2025: Why We Should Be Concerned. Consultative Group on International Agricultural Research (CGIAR), Washington DC.

[6] Kuyiah, J.W. (2007) Economic Analysis of Smallholder Agricultural Production under Conditions of Risk: The Case of Vihiga and Kilifi Districts in Kenya. MSC Thesis, Egerton University, Kenya.

[7] Mateche, D. (2011) Environmental Security Programme. Institute of Securities Studies, Nairobi. 
[8] Kaguongo, W., Gildemacher, P., Demo, P., Wagoire, W., Kinyua, P., Andrade, J., Forbes, G., Thiele, G. and Fugile, K. (2007) Farmers Practices and Adoption of Improved Potato Varieties in Kenya and Uganda. Maastridit School of Management.

[9] Ministry of Agriculture (2007) Annual Report for 2007.

[10] Neumann, L. (2000) Social Research Methods Quantitative and Qualitative Approach. Allyn and Bacon, Boston.

[11] KNBS (2009) Kenya Population Census Report. Ministry of Planning and Vision 2030, Nairobi.

[12] Olanya, O., Lunjaho C., Nderitu. S., Kabura, J., El-Bedewy, R. and Waling, A. (2006) Yield Performance and Release of Four Late Blight Tolerant Potato Varieties in Kenya. Journal of Agronomy, 5, 57-61. 
Scientific Research Publishing (SCIRP) is one of the largest Open Access journal publishers. It is currently publishing more than 200 open access, online, peer-reviewed journals covering a wide range of academic disciplines. SCIRP serves the worldwide academic communities and contributes to the progress and application of science with its publication.

Other selected journals from SCIRP are listed as below. Submit your manuscript to us via either submit@scirp.org or Online Submission Portal.
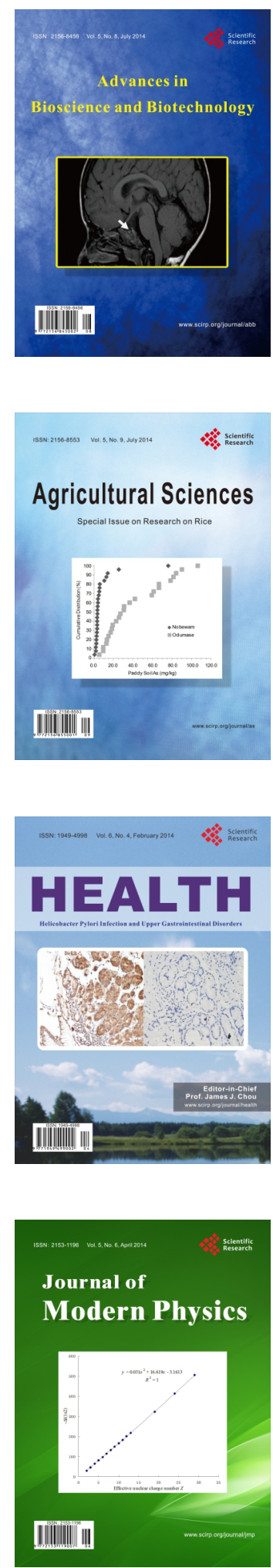
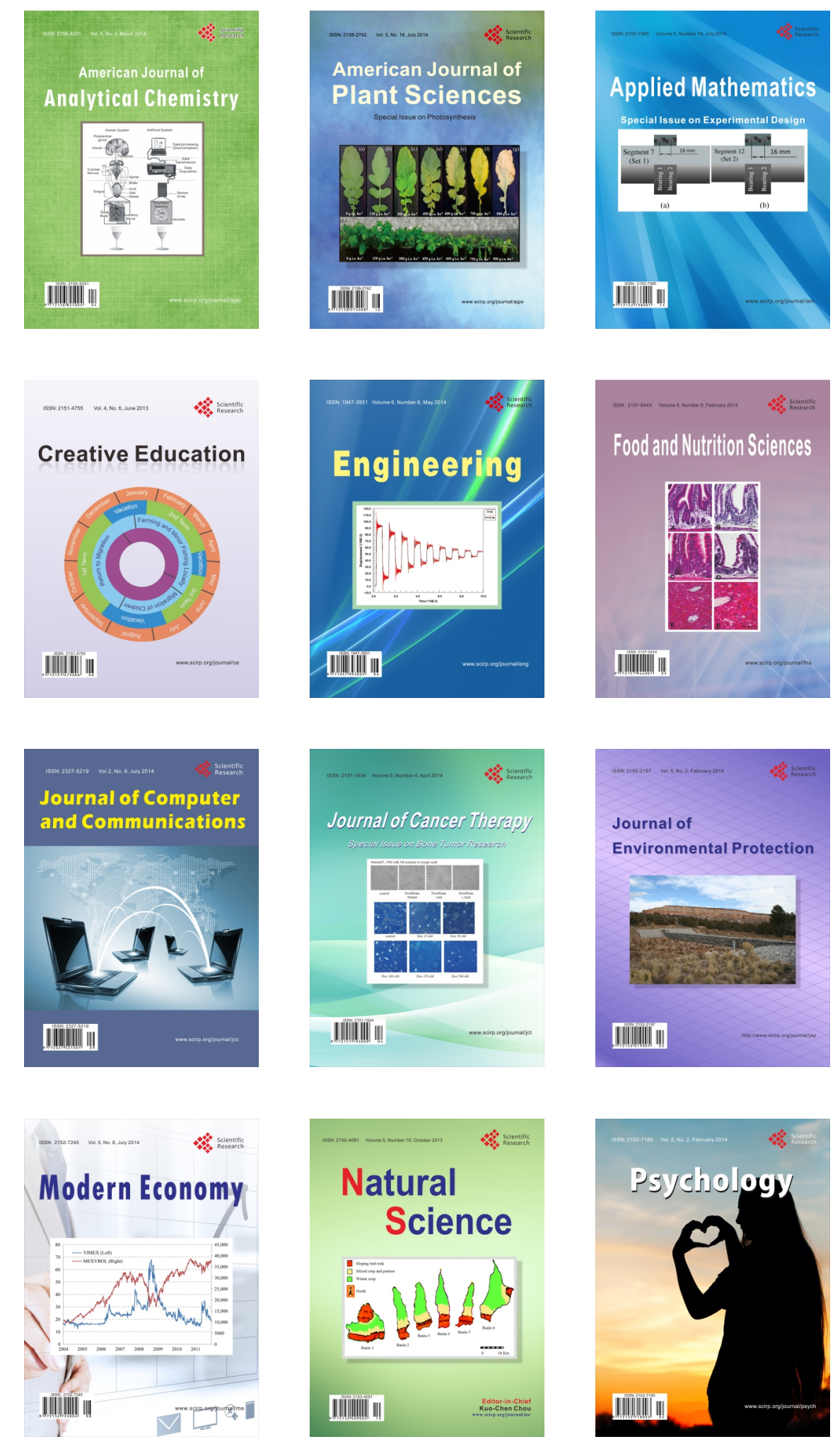